\title{
Rok Svetlič
}

\section{Možne perspektive za pozitivno interpretacijo pandemije COVID-19}

\section{Uvod}

Izhajamo iz podmene, da je pandemija COVID-19 prinesla fisuro v horizont možnega, ki se je vzpostavil v povojni Evropi, zlasti po padcu berlinskega zidu. Lahko bi jo opredelili kot negacijo samoumevnosti, da smo na varnem območju predvidljivega. Sprva mimobežne novice iz nepoznanega mesta Wuhan so postale dominanta javnega interesa, seveda ne brez razloga. Destruktivni učinki pandemije so se manifestirali na vseh ključnih ravneh delovanja družbe, od gospodarstva do zdravstvenih sistemov. Zato razprava o COVID-19 ne more mimo tematizacije tovrstnih posledic, ki jih ima in jih bo še imela na naša življenja. Tudi ob največjih naporih se, denimo gospodarske razmere še nekaj časa ne bodo konsolidirale. To implicira vrsto tveganj, vse od geneze populizmov in prekarnosti zaposlitve do oddaljevanja od ekološke perspektive.

S stališča neštetih destruktivnih posledic je pristop tega prispevka provokativen kontrapunkt: ${ }^{1}$ tematizirali bomo možnost, da bo pandemija prinesla tudi pozitivne učinke. Če že odpiramo možnost pozitivnih učinkov pandemije, najprej pomislimo na instrumentalne odzive, na izboljšave sistemov, ki so pokazali največjo ranljivost. To gotovo drži: zdravstveni sistem, zaloge zaščitne opreme, informacijska družba itd. so področja, ki bodo nedvomno deležna večje pozornosti. Toda v pričujoči razpravi bomo šli dlje, naslovili bomo možnost, da bi lahko pandemija injicirala revizijo razumetja človekovega bivanja in sobivanja - možnost torej, da pride do sprememb na ravni človekovega ethosa, razumljenega v izvornem grškem pomenu, kot človekovega bivališča v celoti bivajočega.

$\mathrm{V}$ ta namen se bomo posvetili filozofskim konceptom, ki so nam kot kulturi, zavezani pacifizmu in človekovim pravicam, težko dostopni. Gre za koncepte, ki eksistencialno stisko človeka - v našem primeru: negotovosti, vključno s strahom pred smrtjo, vznikom političnih tveganj, gmotno brezperspektivnostjo itd. - interpretirajo kot nepogrešljivo človeško izkustvo, ki ga napoti k izvornemu odnosu do sebe in sveta.

1 V aktualnih razpravah zato prevladujejo teme nasilja in izrednih razmer (Happe, 2020), vznika patologij v medsebojnih odnosih (Condit, 2020), etičnih tveganj, ki jih prinaša ideologem "prostega časa» (Salazar, 2020) ipd. 
Dolgo obdobje izobilja in stabilnosti omogoča, prvič, (na lastnini utemeljeno) afirmacijo materialnega in (na svoboščinah utemeljeno) utrjevanje zasebnega (to naj bi - kot bomo videli v nadaljevanju - vodilo v spiralo slabe neskončnosti in posledično v odtujevanje človeka samemu sebi). In drugič, ustvarja vtis viabilnosti politik, ki temeljijo na metafizični predpostavki absolutne razpoložljivosti bivajočega. Z drugimi besedami, utrjuje se predstava, da je sprejemanje (novih) zakonov, direktiv, smernic itd. omnipotenten instrument za upravljanje s svetom. Človek je bitje, ki se mora afirmirati drugače kot (le) v predvidljivi materialni satisfakciji (iz družbe iztrganega) zasebnika. In svet je več kot absolutna pasiviteta, stoječa na razpolago za takšno ali drugačno uobličenje.

Toda teoretsko opozarjanje na pomanjkljivosti teh dveh pristopov, naj bo še tako prepričljivo, ima svoj domet. Če parafraziramo Marxa, bi lahko rekli, da če gremo s "frazami nad fraze«, ne dosežemo prav veliko. Za spremembe je potreben »materialni« dogodek. In prav pandemija kot nepričakovan vdor v horizont možnega je (morda) dogodek take vrste. Na vprašanje, ali bo pandemija dejansko prinesla določen premik, ta trenutek ni mogoče odgovoriti. Vsekakor pa je artikulacija perspektive za pozitivno interpretacijo pandemije - četudi zgolj možne perspektive - naša etična dolžnost.

\section{Ireduktibilna vrzel v človeku}

Posvetili se bomo dvema avtorjema, Ibn Haldūnu in G. W. F. Heglu. Kljub temu, da sta tako časovno kot konceptualno izjemno oddaljena, pri obeh naletimo na nauk, po katerem je (občasno) eksistencialno tveganje nujno ${ }^{2}$ za vitalnost duha neke skupnosti. Ibn Haldūn in G. W. F. Hegel sta avtorja, ki se gibljeta tostran naivnega socialnega optimizma. Zavedata se, da tudi idealiter ne obstaja enačba človekovega bivanja in sobivanja brez preostanka. Toda prav to hrepenenje je v veliki meri zaznamovalo zadnja stoletja naše zgodovine. Gre za hrepenenje, ki je porajalo človekov angažma pri določilih, ki so poprej sodila na področje krščanske eshatologije. Filozofija in znanost sta v določenem trenutku verjeli v t. i. »evangelij čistega uma«, v zmožnost mišljenja, da na ravni ideala ali celo dejansko s sveta odstrani vse strukturne pomanjkljivosti človekovega (so)bivanja.

Naivne utopije (so)bivanja - zlasti marksistična in anarhistična - gradijo na predpostavki popolne samotransparentnosti mišljenja. Izhajajo iz dediščine kartezijanstva, ki svojo travmo breztemeljnosti reši z uvidom v sposobnost samoutemeljitve Subjekta.

2 Preden se posvetimo prvemu, moramo izpostaviti, da je ta teza diametralno nasprotna celotnemu vrednostnemu horizontu, ki zavezuje Zahod po drugi svetovni vojni. Socialna demokracija, temelječa na človekovih pravicah, vse stavi ravno na redukcijo tveganj: od varnostnih, socialnih, ekonomskih, političnih in ekoloških do zdravstvenih in kibernetskih. Nadzorovati skuša že nezaželene oscilacije na teh področjih, o tem, da bi se horizont predvidljivega v celoti vdrl, ne znamo niti razmišljati. Družbo smo se naučili jemati kot preračunljivo in obvladljivo materijo, zato pacifizem, materialno blagostanje in človekove pravice samozavestno razglašamo kot realističen politični cilj brez alternative. In prav ta pogled na tveganja prinaša sam po sebi veliko tveganje. 
S tem se hkrati postavi tudi najvišji standard evidence za spoznanje resničnega: clara et distincta perceptio. Vse, kar obstaja, obstaja znotraj prostora refleksivne strukture mišljenja ter je dostopno v jasni in razločni predstavi. Od tu izvira ideja absolutnega vedenja, s katerim se konča Heglova Fenomenologija duha ali Marxov uvid v »uganko zgodovine« (Marx, 1969a, 332/3).

Vendar je, kar se tiče koncipiranja absolutnega spoznanja, med Marxom in Heglom pomembna razlika. Ta ni (le) na osi idealističnega in materialističnega pristopa, na ravni postavljanja filozofije $\mathrm{z}$ "glave na noge«, marveč na ravni strukture mišljenja samega. Heglova misel je spekulativna, kar mu omogoča uvid, da je absolutna vednost absolutna le tedaj, ko se zaveda tudi meja absolutne vednosti. Zato je absolutna samoprezenca tista, ki ve za nezmožnost "popolne« samoprezence in zna ta moment nepopolnosti vgraditi v samoprezenco samo.

Tudi pri Ibn Haldūnu je povsem jasno, da se posameznik ne more dokopati do absolutne vednosti kot popolnega (znanstvenega) uvida. Poleg tega meni, da sama znanstvena vednost ni koristna pri vodenju skupnosti. Pomenljiva je njegova pripomba, da »naj tisti, ki izvaja oblast, ne bo preveč ostroumen (...) «, ker "pretirano bistroumje in pamet za politika nista primerna, saj pomenita pretiravanje $\mathrm{v}$ mišljenju, tako kot topost pomeni pretirano duhovno negibnost. Obe skrajnosti sta pri vseh lastnostih človeških bitij vredni graje, srednja pot pa je vredna hvale« (Ibn Hुaldūn, 2009, 110). Facit: pri vodenju skupnosti ne gre staviti na »absolutna vedenja« ali »rešene uganke zgodovine«.

Pri obeh avtorjih tako najdemo tematizacijo momenta nesvobode, ki je vgrajen $\mathrm{v}$ vsako mišljenje in hotenje. Mišljenje in hotenje vsakega posameznika sta - tudi če se mu zdi, da je dosegel popolno samoprezenco pri presojanju ciljev - določena z ireduktibilnim elementom negacije tega mišljenja in hotenja. Zato se, tako učita Ibn Haldūn in Hegel, težnja po zagotovitvi nadzorovanega življenja sčasoma sprevrže v svoje nasprotje. Akterji ravnajo v najboljši veri, toda svoboda takega mišljenja in hotenja je omejena s strani intervencije neizogibnega procesa $\mathrm{v}$ »stalni naselitvi« (Ibn Haldūn) ali »zvijačnosti uma« (Hegel), ki determinirata aberacijo v intendiranih smotrih.

Pandemija kot "pozitiven « dogodek: morda prinaša nepričakovan "materialen « vdor v dominantno razumetje človekovega (so)bivanja in s tem priložnost za revizijo njegovega ethosa. To je priložnost, ki ima veliko prednost pred drugačnimi prelomi. Kadar moment nesvobode v svobodi pripelje do revizije nekega narativa, se to manifestira v eroziji stabilnosti družbenega reda. Tveganja, povezana s tem, so izjemna, vključujoč (oborožene) konflikte. Zato je prednost pandemije, da lahko prinese prelom umestitve človeka v svet brez posledic, kot jih prinašajo konflikti. Kant v svoji viziji »večnega miru « (Kant, 2006) govori o dolžnosti izogibanja dejanjem, ki preprečujejo zaupanje med sprtimi tudi po koncu konfliktov. Iz izkušenj vemo, da spopadi pogosto ustvarijo globoke sledi, ki se še desetletja ne pomirijo. Pandemija, nasprotno, s tega vidika države prej konsolidira kot razdvaja. 


\section{Ibn Haldūn in »stalna naselitev«}

Ibn Haldūn (1332-1406) je v marsičem na novo odkrit avtor, ki je v Evropi postal »ne samo cenjen, temveč že kar v modi« (Svetlič, 2009, 261). Izmed številnih področij, ki jih je raziskoval, tukaj izpostavljamo le njegov nauk o poteku zgodovine, ki ga razgrne na opisu prehoda od nomadske do stalno naseljene oblike sobivanja. V Uvodu $v$ knjigo primerov zapiše, da ga zanima »notranje « zgodovinopisje, ki bo zmožno opisati in razumeti temelje dogajanja $v$ zgodovini: »V notranjosti zgodovinopisja pa gre za motrenje, preverjanje in natančno raziskovanje bivajočih stvari in njihovih temeljev ter globoko poznavanje kakršnihkoli dogodkov in njihovih vzrokov« (Prav tam, 9). Prav tej perspektivi bomo posvetili pozornost.

Interes za raziskovanje procesov v družbi je Ibn Hुaldūn dobil na osnovi politične izkušnje tistega časa. Mağrib, severozahodna Afrika, je bila soočena s političnimi krizami in vsiljevalo se je vprašanje, ali islam sploh razpolaga $z$ institucijami, ki lahko zagotavljajo družbeno ureditev: »Kriza vladanja, s katero se soočajo islamske institucije med 10. in 14. stoletjem, spominja v temeljnih potezah na tisto (krizo vladanja), ki je navzoča od 18. stoletja do danes: šlo je namreč - in še vedno gre - za vprašanje, ali zmorejo institucije, ki jih je ustvaril islam, zagotoviti vladavino«(Rothholz, 1985, 309). Mehanizem, ki vodi potek zgodovine, opiše s pomočjo razlikovanja med nomadskim in stalnim načinom življenja ter njunim medsebojnim prehajanjem. Opis začne pri beduinskem načinu življenja.

Čeprav Ibn Haldūn razmišlja na način, ki je oddaljen od idealiziranja, pri opisovanju beduinskega življenja ne skopari s superlativi. Zapiše, da so beduini »bliže dobremu« (Ibn Haldūn, 2009, 33): so borbeni, vztrajni ter predani skupnosti. Zato ima tak način življenja tako časovno kot logično prioriteto pred stalno naseljenim: »Nomadsko življenje je torej zibelka stalno naseljenega življenja ter časovno starejše« (Prav tam, 32). Vzrok za to so trde razmere, ki od vsakogar terjajo polno predanost plemenu in brezpogojno žrtvovanje. Dostop do dobrin je skrajno omejen, zaradi česar lahko dosežejo zadovoljitev zgolj najnujnejših potreb.

Zadovoljevanje zgolj najnujnejših potreb pomeni hkrati - tu se začne opisovanje mehanizma, ki predrugači namene posameznikov - negacijo svetnosti. Z drugimi besedami, dobrine (lastnina, hrana, prebivališča itd.) imajo zgolj instrumentalni značaj in v nobenem primeru niso smoter na sebi. Posledično ne morejo postati del mehanizma, ki bi narekoval notranjo dinamiko beduinskih skupnosti. To se bo obrnilo na glavo pri stalni naselitvi, kjer prebivalci v prvo vrsto postavijo stremljenje po izobilju zaradi izobilja. Poseben pokazatelj vitalnosti beduinskega načina življenja je v polnosti razvit čut za skupnost) 'așabìya). Le popolna predanost skupnosti namreč lahko v neizprosnih razmerah omogoči njeno preživetje.

Nomadskemu načinu življenja sledi stalna naselitev. Tu pride na delo moment nesvobode $\mathrm{v}$ svobodi, ki povzroči, da se z naselitvijo nehote začne erozija skupnosti. 
$\mathrm{V}$ teh razmerah dve strasti, »ki sta naravnani na užitek in lastnino« in sta bili »v fazi nastajanja in konsolidiranja potlačeni (...), sčasoma pridobivata na intenziteti, vse dokler ne prevladata nad težnjo po oblasti« (Rothholz, 1985, 309). Gre za neizprosen mehanizem, ki vdira v posameznikovo mišljenje in hotenje, če on to hoče ali ne. V zvezi s tem je najbolj znana Ibn Haldūnova doktrina o procesu propadanja »dinastije«, ki se odvije v treh generacijah: "Vedi, da naravno življenje obdobja dinastije po navedbah zdravnikov in astrologov znaša sto dvajset let « (Ibn Haldūn, 2009, 97) in »večinoma ne presega treh generacij« (Prav tam, 98).

Prva generacija »ostane zasidrana v značilnih lastnostih puščavskega življenja« (Prav tam), kar se izraža v neustrašnosti in divjosti njenih članov. Čut za skupnost je razvit do najvišje stopnje. Druga generacija pa se spričo udobja že premakne k značilnostim stalne naselitve. Slava, ki jo je poprej delilo celotno pleme, zdaj pripade enemu, »drugi se pa prepustijo lenobnosti in se ne potegujejo zanjo«. S tem se odpre tudi pot od »časti nadvlade do ponižanja podjarmljenja« (Prav tam). Čut za skupnost erodira, zamenja ga poslušnost. Kljub temu vrline puščavskega življenja še niso povsem izgubljene, saj je druga generacija vendarle imela neposreden stik s prvo.

Prav to je ključna okoliščina, ki pri tretji generaciji umanjka. Neizprosne razmere in nomadsko življenje je pozabljeno in njeni pripadniki živijo, »kot da ne bi nikoli obstajalo« (Prav tam, 99). Čut za skupnost dokončno izpodrine podvrženje vladarju, hkrati pa se razkošje prebivalcev izrodi do skrajnosti: »Postanejo oskrbovanci dinastije, tako kot so ženske in otroci. (...) Ljudi zapeljejo zunanjost, oblačila, ježa na konjih, lišp, s katerim se kitijo «(Prav tam). Taka dinastija postaja notranje izvotljena, s čimer je njena usoda zapečatena: "Nato dinastija, z vsem, kar spada k njej, izgine» (Prav tam). Na empirični ravni se lahko njeno življenje sicer nekoliko podaljša, če pač ni soočena z nobenim izzivom, toda njeno načelno pogubljenost Ibn Haldūn opiše z besedami: „Če je življenjsko obdobje dinastije poteklo, ga nihče ne more podaljšati ali skrajšati niti za eno samo uro «(Prav tam, 99/100). ${ }^{3}$

Seveda kulturni in časovni kontekst teh analiz ne omogočata neposrednega prenosa v našo duhovno situacijo. Kljub temu pa je mogoče njihovo analogno branje na dveh ravneh.

Prvič, opisano erozijo vitalnosti skupnosti lahko zajamemo v terminih družbene participacije in demokratičnega deficita. Pri tem je mogoča vzporednica s povojnim

3 V Uvodu najdemo opis še enega, analognega procesa degeneracije, ki pa ga vodi isti mehanizem. Gre za »imenitnost« nekega rodu, ki se razvodeni v času štirih generacij. Tisti, ki jo gradi, pozna ceno zanjo. Sin sicer ima stik z očetom, toda za njim zaostaja »tako kot tisti, ki je o nečem slišal, zaostaja za onim, ki je zadevo videl na lastne oči« (Ibn Haldūn, 2009, 58). Tretja generacija je obsojena na še večjo oddaljenost od izvora imenitnosti rodu in lahko doseže raven zgolj slepega posnemanja. Četrta pa je že »izgubila vse značajske lastnosti, ki so omogočile gradnjo slave« (Prav tam, 58), pri čemer je njena najhujša napaka prepričanje, da slava pripada nekomu zgolj zaradi rojstva. Niz štirih generacij tako vključuje »enega graditelja, tistega, ki je bil z graditeljem v osebnem stiku, tistega, ki je sledil izročilu, in rušilca« (Prav tam, 59). 
razumetjem odnosa med posameznikom in skupnostjo ter njegovim nadaljnjim razvojem. Po utrujenosti generacije, ki je doživela drugo svetovno vojno, druga generacija hrepeni po boljšem svetu in potegne največ iz tega, kar obdobje stabilnosti omogoča. Gre za izgradnjo socialdemokracije evropskega tipa, ki je država blaginje, socialne varnosti, dostopnosti javnega šolstva in zdravstva ter neprestanih emancipatornih procesov na vseh ravneh.

Tretja generacija - recimo, da je to generacija zdaj aktivnih posameznikov - pa živi v samoumevnosti stabilnosti in izobilja. To velja vsaj za »zahodno« Evropo, ki se ji postsocialistične družbe v tem smislu naglo približujemo. Živi, kot da časi negotovosti, tveganj in pomanjkanja v Evropi »ne bi nikoli obstajali«. Zato ta generacija težko razume pomen države in državljanske solidarnosti za zagotavljanje stabilnosti in redukcije tveganj na vseh ravneh, ki jo uživa. V njenih konstitutivnih resorjih (pravosodje, policija, vojska) prepozna le (proto)represivne organe ali vsaj nepotreben strošek.

Sebe vse manj vidi kot del (aktivnega) demokratičnega življenja države, interes za javno in udeležba na volitvah upadata. Apriorno nasprotuje vsaki državni regulativi, ki omejuje svoboščine, četudi še tako upravičeni. Dovolj je, če v zvezi s tem omenimo srdit upor zoper pandemične ukrepe (od testiranja do cepljenja) pri nas in širom po EU. Hkrati pa ta generacija vse več (pasivno), kot »oskrbovanec dinastije«, pričakuje od države: prevzemanje tveganj, transferje, subvencioniranje in uvajanje novih intervencionističnih politik. Odmiku od javnega, na drugi strani, ustreza vse večja afirmacija zasebnega. Ta je v nekaj desetletjih pripeljala do malodane »baročne« opreme življenja slehernika (od samoumevnosti rednih potovanj širom po svetu, prek groteskno izumetničene kulinarične ponudbe do avtomatskih sesalnikov in kosilnic v naših domovih - če naštejemo nekaj banalnih primerov). Z Ibn Haldūnom: »Zunanji pomp in blišč zavzameta mesto v dušah ljudi« (Prav tam).

In drugič, ne obstaja niti pogoj možnosti, da bi se ta generacija zoperstavila premikom, ki so se zgodili. Ibn Hुaldūn zapiše, da se včasih resda najde kdo, ki bi rad razuzdano življenje mesta vrnil k pravemu odnosu do materialnega blagostanja. Toda »kdor je videl, kako se njegov oče in večina njegovih svojcev odeva v svilo in brokat (...), temu ni mogoče, da bi ravnal v protislovju s svojimi predniki, si nadel robat površnik in nošo ter se pomešal med ljudi. (...) Če bi se kljub temu tako vedel, bi se ga obdolžilo norosti in zlih prišepetovalcev s strani satana, ker je tako naenkrat opustil navade. Pretila bi nevarnost, da bi to imelo slabe posledice na njegovo vladanje« (Prav tam, 122). Avtopoetični mehanizem "navad « postavlja neomajne gabarite vladanju, zato tudi morebiten uvid vladarju ne omogoča preusmeriti toka zgodovine.

Zdi se, da lahko, četudi z vso previdnostjo, potegnemo vsaj delno analogijo z našo duhovno situacijo. Vsako omenjanje državne solidarnosti, Ibn Haldūnovega »čuta za skupnost«, denimo v podobi patriotizma ali vsaj lojalnosti do države, bi bilo apriori narobe razumljeno. Kdor bi se zavzel za kaj takega, »bi se ga obdolžilo norosti«: 
nazadnjaštva, antiliberalizma in etatizma. Vsako opozorilo, da je selitev proizvodnje celotnih panog (na primer zaščitne opreme) na Daljni vzhod nedopustno tveganje, bi bilo zavrnjeno kot presežena doktrina etatistične avtarkije. In tako dalje. Če bi neka oblast pri tem kljub temu vztrajala, bi pretila »nevarnost, da bi to imelo slabe posledice na (njeno, op. R. S.) vladanje«.

Ibn Haldūn vidi le en način, ki lahko preseka ta avtopoetični mehanizem erozije: eksistencialni pretres. Govori o vzniku novih civilizacij, ki nastanejo tako, da si »upravitelji obrobnih pokrajin, ko se senca vpliva dinastije $v$ teh pokrajinah zmanjša, prisvojijo izključno oblast nad njimi« (Prav tam, 128), ali pa tako, »da se nekdo iz dinastij sosednjega ljudstva ali plemena dvigne proti njej« (Prav tam, 129). Torej, v modernem jeziku, prek oboroženega konflikta.

Prednost pandemije pa je ravno v tem, da lahko prinese nastanek »nove civilizacije«, ne da bi se poslovili od pacifistične vizije Evrope. Ibn Haldūnov opis nastanka nove civilizacije lahko beremo kot porajanje nove vitalne sile, nekakšne așabìye - danes bi rekli (novega) načela solidarnosti -, ki jo lahko spravi na plano pandemija. V kakšni podobi se lahko zgodi ta revitalizacija, kot smo pojasnili uvodoma, ta trenutek ni mogoče reči. Naša dolžnost je le, da jo znamo pričakovati. Človekovo bistvo namreč je, če uporabimo besede M. Heideggerja, »da je čakajoči, ki čaka bistvo biti s tem, da ga misleč varuje» (Heidegger, 1967, 370).

\section{Hegel in "antiburžoazni afekt»}

Gotovo je presenetljivo, da podobno analizo destruktivnosti blagostanja in stabilnosti najdemo pri avtorju, ki je od Ibn Haldūna tako časovno kot tematsko oddaljen cela prostranstva. Seveda je pri Heglu nespregledljiv pečat kartezijanstva, krščanstva s konceptom troedinosti na čelu, in neštetih drugih miselnih tokov. Toda tudi on izjemen filozofski interes posveti zgodovini in njenemu poteku, tistemu torej, kar Ibn Haldūn imenuje "notranji vidik « zgodovinopisja. In prav na tem področju se izpeljave obeh avtorjev presenetljivo približajo. Gre za Heglovo filozofsko analizo zasebnika kot bourgeoisa, buržuja.

Buržuj je iz družbe izoliran posameznik, ki se orientira v mediju samovolje (die Willkür) in zato v sebi nima meje. Na družbo in na druge zasebnike se naslavlja le v intenci maksimizacije zasebne koristi. Zato mora zamejitev buržuja - G. H. H. Falke, denimo, Heglovo celotno filozofijo opredeli kot poskus, kako »zamejiti buržuja« (Falke 1996) - izvajati država z zakonodajo in svojimi institucijami. Toda pri tem država nima zadnje besede. Oris filozofije pravice se po analizi državnega organizma nadaljuje s prehodom v svetovno zgodovino. To je edini način, na katerega so lahko partikularne države presojane skozi univerzalno instanco: skozi »um v zgodovini« (Hegel 1999b). Posamezne države v medsebojnih odnosih namreč ostajajo na ravni samovolje, kjer so možni zgolj dogovori, (bilateralne ali multilateralne) pogodbe. 
V temelju so države v (latentnem) naravnem stanju ( $\$ 333$ ), saj ima meddržavno pravo zgolj značaj najstva, torej ni dejansko. ${ }^{4}$ Univerzalnega reda v tej situaciji ne more zagotoviti planetarna družbena pogodba z ustanovitvijo nekakšne »nad-države « kot planetarnega suverena. ${ }^{5}$ To univerzalnost Hegel prepozna v svetovni zgodovini, saj izkazuje umen potek. Nas ne zanima sam potek svetovne zgodovine, pač pa naslednje: prvič, spoznanje, da samovolja kot medij odnosov med državami vodi v antagonizem partikularnih interesov in posledično v možnost (vojaških) konfliktov med državami; in drugič, afirmativna presoja teh konfliktov, ki jim Hegel pripisuje nravni značaj - podobno kot Ibn Hुaldūn izkušnji trdega življenja beduinov. Po Heglu pacifizem ni le nerealen, pač pa tudi nenraven, saj dopušča učvrstitev sfere buržuja in njegovo iztrganje iz državne celote. Ali je Hegel zaradi zavračanja pacifizma belicist?

$\mathrm{S}$ stališča dominantnega pacifističnega etosa je razumljivo, da je bila Heglova fascinacija $\mathrm{z}$ vojno in njenim nravnim značajem deležna očitka belicizma. Če upoštevamo učinkovno zgodovino njegove filozofije $\mathrm{v}$ desnoheglovskih interpretativnih tokovih, se zdi, da je ta sodba toliko bolj upravičena. Tako sta na primer C. Rössler in A. Lasson, kot opozarja H. Ottmann, Hegla štela »za utemeljitelja nacionalne države moči (Machtstaat) (...) in za zagovornika vojne« (Ottmann, 2005, 269). Angleški filozofi, na primer K. Popper, vlečejo celo lok od Hegla do totalitarističnih ekscesov druge svetovne vojne.

Marsikatera mesta se dejansko zelo približajo belicistični doktrini, denimo izpostavljanje pozitivnih učinkov vojne pri reševanju mirnodobnih izzivov. Tako Hegel piše, da so »srečne vojne preprečile notranje nemire in utrdile notranjo državno oblast« (324). Težko se je izogniti vzporednici, ki se na tej točki vsiljuje s stališčem G. Gentileja, utemeljitelja italijanskega fašizma: "Za nekatere je bilo bistveno vstopiti v vojno: skupaj z Nemčijo ali proti Nemčiji. Vstopiti v vojno in vreči narod, če to hoče ali ne, v konflikt - ne zaradi Trenta, Trsta ali Dalmacije; (...) Toda vstop v vojno je bil potreben, da bi končno poenotili narod s pomočjo prelivanja krvi« (Gentile, 2009, 2).

Toda Heglovega odnosa do vojne ni mogoče reducirati niti na posamezne pasuse niti na eno vejo njegove učinkovne zgodovine. Prav tako zavračanje pacifizma, denimo v podobi Kantovega »večnega miru«, ne pomeni eo ipso afirmacije njegove enostavne antiteze. Če belicizem razumemo kot nauk, ki vidi vojno kot poglavitni instrument za reševanje vseh odprtih političnih vprašanj, instrument, ki ga je treba uporabiti prioritetno in brez pomislekov, potlej je treba ugotoviti, da je Heglov pogled na vojno

4 Hegel si ne zna zamisliti takega mednarodnega prava, ki je zlasti po drugi svetovni vojni doživelo največji razmah. Tudi danes mnogi dvomijo o tem, da je mednarodno pravo pravo v pravem pomenu besede, tj. sistem, ki zagotavlja pravice posamezni državi neodvisno od njene dejanske politične in vojaške moči. To potrjujejo številni primeri in zdi se, da vsaj delno še vedno velja, da nad državami ni ničesar, kar bi jamčilo za njihove medsebojne odnose. 
vendarle drugačen. Eden od avtorjev, ki Hegla jasno ločuje od belicizma, je že omenjeni H. Ottmann, ki argumentira takole: »Hegel ni belicist. Vojno opredeli kot 'nekaj, kar naj bo prehodno' (Vorübergehensollendes), in nekaj, kar mora biti naravnano na 'možnost' bodočega miru. Hvalnica 'nravnosti' vojne, ki je za mnoge tako škandalozna - in jo v prav takem tonu sicer najdemo tudi pri Kantu -, pri Heglu ne izvira iz belicizma, pač pa iz antiburžoaznega afekta« (Ottmann, 2005, 273).

Ta argument vsebuje dve ravni. Najprej, Hegel dejansko nikjer ne poziva k brezobzirnemu in slepemu vojskovanju. Omenjeni $₫ 338$ jasno postavlja meje, saj je vojna najprej »določena kot nekaj, kar naj bo prehodno«, poleg tega pa se je »ne sme voditi zoper notranje institucije, mirno družinsko in zasebno življenje in zasebnike« (\$338). Druga raven argumenta pa izvor Heglovega odnosa do vojn pojasnjuje $\mathrm{z}$ »antiburžoaznim afektom« in je za namen tega članka ključna. Gre za »afekt«, ki izvira iz Heglovega uvida $v$ napetost med (njegovim) pojmovanjem države in destruktivnimi učinki, ki jih ima nanjo sfera zasebnika v podobi občanske družbe (bürgerliche Gesellschaft).

Država ni zgolj agregat posameznikov. Če teorija družbene pogodbe uči, da so posamezniki pojmovno pred državo, je za Hegla situacija ravno obratna. Na to poleg razvoja pojma države opozarja več okoliščin, omenimo le dve. Prvič, država ima pravico zahtevati žrtvovanje posameznika za njen obstoj, saj je »... absolutna moč napram vsemu posamičnemu in posebnemu, napram življenju, lastnini in njenim pravicam« (Hegel, 1970, \$324). Na prvi pogled se zdi, da je zahteva po žrtvovanju posameznika značilnost totalitarnih ideologij, nezdružljiva $z$ demokratičnim etosom. Toda tudi demokratične ureditve si to pravico pridržujejo. Ustava Republike Slovenije: »(dolžnost sodelovanja pri obrambi države) Obramba države je za državljane obvezna v mejah in na način, ki ga določa zakon« (123. člen).

In drugič, brez državnega intervencionizma občanska družba kot sfera sklepanja pogodb, ki je »slepa in pogreznjena v samoljubne smotre (Hegel, 1970, § 236), zaide v samodestrukcijo. Samovolja (die Willkür) zmore le parcialno, instrumentalno orientacijo: ekonomija kopiči in ne misli. To se kaže v gospodarskih nihanjih ( $\$ 236$ ), v nastajanju revščine (\$244), v mehanizaciji in drobljenju dela, zaradi česar stroj zamenjuje človeka (\$198) ter v dekadentnem stopnjevanju udobja v neskončno (\$191). Zato sta nujna »nadzor in preventiva s strani javne oblasti« (\$235), tj. državni intervencionizem. F. Schick opozarja, da »ni povsem brez protislovja, če v konico politične filozofije postavimo tak interes, ki izkazuje tako malo umnosti, da za svoj obstoj trajno potrebuje zunanjo silo« (Schick, 2009, 34), tj. državno intervencijo.

Heglov »antiburžoazni afekt«: posameznik in njegovo sklepanje (družbenih) pogodb ne moreta pojasniti takega organizma, kot ga predstavlja država. Nasprotno, posameznik je poglavitni destruktivni element v državi. Zato država brzda defekte, porajajoče se iz samoljubja posameznikov, vendar so pri tem njene moči omejene. In na tej točki se začenja utemeljevanje nravnega značaja vojne: le siloviti dogodki (vojne, vendar ne le vojne! - podrobneje v nadaljevanju) so sposobni načeti moč in samostojnost 
občanske družbe, nekakšne države v državi. Nikakor ne gre zgolj za instrumentalno premagovanje "notranjega sovražnika«, pač pa za proces, ki naredi sam pojem države dejanski. Lastnina, varnost, življenje, vse to ima značaj končnosti. Idealiteta države temelji na neprestanem toku negacije končnega in nravni značaj vojne je prav v tem, da to zagotovi: »V tem je nravni moment vojne, ki je ne smemo obravnavati kot absolutnega zla in kot zgolj zunanje naključnosti. (...) Nujno je, da je tisto, kar je končno, posest in življenje, postavljeno kot naključno, saj je naključnost pojem končnosti« (Hegel, 1970, § 324).

Da je zadovoljitev v materialnem nekaj končnega, je splošno pripoznano stališče, potrjeno tudi v vsakdanji retoriki ljudi, ki pa sami tega spoznanja ne vzamejo resno. Za to do določene mere skrbi država s svojimi institucijami (intervencionizmom), kjer pa se njena moč konča, to vlogo prevzamejo (med drugim) vojne: »Vojna je stanje, v katerem piškavost minljivih reči, kar je sicer le vsakdanje govoričenje, postane nekaj krvavo resnega « (\$324). Le če je končno postavljeno kot končno, le če izkusi svojo naključnost, tedaj je organizem države tekoč. Hegel uporablja metaforo »okostenelosti« in »zdravja«: »V miru se meščansko življenje (bürgerliches Leben) bolj širi, vse sfere se bolj in bolj udomačujejo, in na dolgi rok to naredi človeka topega; njegove partikularnosti postajajo vse bolj trde in okostenele. Toda k zdravju sodi enotnost telesa, in če deli otrdijo, to vodi v smrti« (Prav tam).

Te izpeljave, podobno kot Ibn Haldūnove, lahko pomenijo horizont za interpretacijo pandemije. Gre za dogodek, ki je nepričakovano vdrl globlje v uveljavljen horizont možnega in ga predrugačil bolj kot katerakoli druga kriza v Evropi po drugi svetovni vojni (izvzemši vojne na Balkanu v 90. letih). Hkrati pa ni vnesel negotovosti prek oboroženega konflikta, pač pa prek zdravstvene ranljivosti človeka. In prav to možnost Hegel eksplicitno omeni kot enega od načinov, da končno izkusi nujnost, ki bdi nad njim: »Ta nujnost ima po eni strani podobo naravnega nasilja, vse končno je umrljivo in minljivo« (Prav tam). Druga možnost pa je vojna. Vojna torej ni edini način, da »se 'ohrani nravno zdravje ljudstev in njihova ravnodušnost do okostenelosti končnih določenosti, kot gibanje vetrov obrani morje pred gnilobo, $\mathrm{v}$ katero bi se pogreznilo ob trajnem brezvetrju, tako kot ljudstva ob trajnem ali celo večnem miru'« (Prav tam). Pandemija lahko opravi isto funkcijo, funkcijo brzdanja nenadzorovane rasti sfere zasebnika, ki je »slepa in pogreznjena v samoljubne smotre« $(\$ 236)$.

Destruktivnost pandemije (ali vojne) ima pri Heglu isti fokus kot marksistična tradicija kritike meščanske države, seveda $z$ vsemi razlikami na ravni metode in cilja: postaviti končno "pod pojem nujnega « pač ni isto kot komunistična revolucija. Čeprav Hegel ne vidi možnosti eshatološke rešitve napetosti med bourgeoisem in citoyenom, bi se kljub temu strinjal z Marxovo kritiko (abstraktne) svobode kot temelja meščanske države: »V čem je liberté? (..) Gre za svobodo človeka kot izolirane, nase 
skrčene monade« (Marx, 1969b, 172). V poglobljeno analizo nadaljnjih razlik med avtorjema ne moremo vstopati. Ključno je, da Hegel v pretresih - kot je (morda) pandemija COVID-19 - vidi priložnost za revizijo statusa zasebne zadovoljitve v odnosu do sfere sobivanja. To vključuje tako novo naravnanost do vitalnih funkcij, ki jih zagotavlja obča organizacija, ${ }^{6}$ kot spremembo človekove umestitve v celoto bivajočega.

\section{Pandemija in porajanje novega}

Doktrini Ibn H్Galdūna in Hegla na določeni ravni gotovo vzbujata etično averzijo in avtomatično napotujeta na vprašanje, ali res ni nobenega drugega načina, da bi človek revidiral odnos do svojega bivanja in sobivanja, kot je eksistencialna stiska - vključno z možnostjo izgube življenja. Pa vendar, naj njuna nauka učinkujeta še tako anahronistično, težko spregledamo, da čas hrepenenja in duhovnega porajanja ni privilegij vsake generacije. In žal taki časi večinoma sledijo velikim pretresom.

Pandemija je dogodek, ki je prišel izza hrbta. Njen pomen je v prvi vrsti v tem, da se je izmuznila celotnemu racional(istič)nemu aparatu za pojasnjevanje sveta. Verjamemo, da razumemo vzroke gospodarske recesije in jih znamo blažiti. Da razumemo vzroke konfliktov v določeni regiji in jih znamo brzdati. Pandemija pa je izbruhnila brez »vzroka« in prav zato spodnesla horizont možnega, ki nam je dajal občutek varnosti. Ta je temeljil na metafiziki prezence, ki je bivajoče razumela kot transparenten sistem, opredeljen s preračunljivimi vzroki: nihil est sine ratione. To je svet brez niča, v katerem je »vse negativno, nično (Nichthafte) že žrtvovano« (Heidegger, 2009, 14).

Pandemija nas spet uči živeti z ničem. Nič ni preračunljiv in ga s pomočjo znanstvenega diskurza ni mogoče udomačiti. Prinaša tveganja, kot jih prinese vojna $-\mathrm{v}$ določenem smislu celo večja, tako po številu žrtev kot po posegu v življenje družbe. $\mathrm{V}$ vojnih razmerah so spopadi večinoma lokalizirani, zato lahko šolanje, gospodarstvo, zdravstveni sistem in drugi podsistemi delujejo razmeroma neokrnjeno naprej. Vse to za pandemijo ne velja. Z lahkoto preskakuje meje, blokira življenje najrazvitejših držav, venomer preti z novimi mutacijami virusa. Prihodnost zgolj enega leta je tu mnogo bolj nepredvidljiva kot pri večini vojaških konfliktov.

Ibn Hुaldūn in Hegel sta avtorja, ki nepreračunljivost sveta vgradita v samo jedro človekove tu-biti. Tveganja so ireduktibilen sopotnik človeka. Ne le, da je nerealno pričakovati svet kontinuiranega blagostanja. Brez pretresov in eksistencialnih izzivov naj bi človek postal tuj samemu sebi kot solidarnemu (Ibn Haldūn) in neskončnemu

6 Verjetno najpomembnejše svarilo, da je senzibilnost za »skupni interes« zdrknila za dominanto partikularnih interesov, je eskalacija in neobvladljivost nedavne begunske krize: »Na žalost je to le eno od številnih vprašanj, s katerimi se sooča EU, in vsako od njih zahteva temeljit premislek ter veliko motivacije in usklajevanja med vsemi udeleženci, seveda ob predpostavki, da jih zanima poleg svojega tudi širši, skupni interes« (Brožič, 2020, 8). 
(Hegel) bitju. Ali bo pandemija COVID-19 spodbudila prelom z dominantnimi narativi zahodne družbe, ni mogoče napovedati, navsezadnje je še ni konec. Če vendarle pride do pozitivnih sprememb, je prav tako nemogoče povedati, kako se bodo manifestirale. Toda nekaj je neizpodbitno: če je taka revitalizacija brez vojne možna, je trenutna pandemija temu najbližje. S pomočjo Ibn Haldūna in Hegla smo v nepreglednem mnoštvu težkih bremen pandemije skušali izluščiti perspektivo, ki govori temu v prid. In četudi je ta perspektiva zgolj možna, je naša etična dolžnost, da jo izrečemo.

\section{Zahvala}

Študija je nastala v okviru raziskovalnega programa »Družbena pogodba v 21. stoletju« (P6-0400), ki ga financira ARRS, Javna agencija za raziskovalno dejavnost Republike Slovenije.

\section{Literatura}

Brožič, L., Migration to the Republic of Slovenia as "A First Step« into the European Union, Sociology and Anthropology, Vol. 8 (3), 2020, str. 72-81.

Condit Celeste, M., Phronesis and the Scientific, Ideological, Fearful Appeal of Lockdown Policy, Philosophy \& Rhetoric 53, št. 3, 2020, str. 254-60.

de Berg, H., Das Ende der Geschichte und der bürgerliche Rechtsstaat, Francke Verlag, Tübingen 2007.

Falke, G. H. H., Begriffene Geschichte. Begriffene Geschichte: das historische Substrat und die systematische Anordnung der Bewußtseinsgestalten in Hegels Phänomenologie des Geistes, Lukas Verlag, 1996.

Gentile, G., Origins and Doctrine of Fascism, v: Gentile, G.: Origins and Doctrine of Fascism, New Jersey, Transaction publishers, 2009, str. 1-34.

Happe Kelly, E., Utopia and Crisis, Philosophy \& Rhetoric 53, št. 3, 2020, str. 272-78.

Hegel, G. W. F., Grundlinien der Philosophie des Rechts, Suhrkamp, Frankfurt am Main 1970.

Hegel, G. W. F., Um v zgodovini, Analecta, Ljubljana 1999b.

Heidegger, M., Tehnika in preobrat; v: Izbrane razprave, Cankarjeva založba, Ljubljana 1967, str. 319-382.

Heidegger, M., Hegel (GA 68), Vittorio Klostermann, Frankfurt am Main 2009.

Ibn Khaldun, Mukadima: Uvod v knjigo primerov, Krtina, Ljubljana 2009.

Kant, I., Ideja k obči zgodovini s kozmopolitskega stališča, v: I. Kant, Zgodovinsko-politični spisi, ZRC SAZU, Ljubljana 2006.

Marx, K., Pariški rokopisi, v: K. Marx, F. Engels: Izbrana dela (MEID), Zvezek I., Cankarjeva založba, Ljubljana 1969a.

Marx, K., Prispevek k židovskemu vprašanju, v: K. Marx, F. Engels: Izbrana dela (MEID), Zvezek I., Cankarjeva založba, Ljubljana 1969b.

Ottmann, H., Die Weltgeschichte, v: Siep, L., G. W. F. Hegel: Grundlinien der Philosophie des Rechts, Akademie Verlag, Berlin 2005, str. 267-286.

Rothholz, W., Bemerkungen zur politischen Theorie Ibn Khaldun's, v: Zeitschrift für Religionsund Geistesgeschichte, Vol. 37, No. 4, 1985, str. 309-321. 
Salazar, Ph. J., The Virus That Dares (Us) Not (to) Speak Its Name: A Polemic, Philosophy \& Rhetoric 53, št. 3, 2020, str. 319-25.

Schick, F., Der Begriff des Verhältnisses von Staat und Religion, v: Staat und Religion in Hegels Rechtsphilosophie (ur. Arndt, A., Iber, C., Kruck, G.), Akademie Verlag, Berlin 2009.

Svetlič, N., Ibn Khaldun - Razgibano življenje nenavadnega moža, v: Mukadima: Uvod v knjigo primerov, Krtina 2009, str. 237-61.

Sveto pismo Stare in Nove zaveze, Svetopisemska družba Slovenije, Ljubljana 2007.

Ustava Republike Slovenije (čistopis), https://zakonodaja.com/ustava/urs (ogled: 27. 5. 2021).

Rok Svetlič

\section{Možne perspektive za pozitivno interpretacijo pandemije COVID-19}

Ključne besede: pandemija, Ibn Haldūn, G. W. F. Hegel, belicizem

Članek se posveča specifičnemu pogledu na pandemijo COVID-19, ki predstavlja izrazit kontrapunkt prevladujočim odzivom nanjo. Namesto analiziranja anomalij, ki jih je povzročila, se bomo vprašali, ali lahko pandemija prinese priložnost za revitalizacijo zahodnega duha. Iskanje novih konceptov sobivanja, ki bodo segli prek materialistične zadovoljitve zasebnika, maksimizacije dobička in s tem povezanih ekoloških izzivov, je stalnica povojne Evrope. Toda trdovraten avtopoetični mehanizem dominantnega narativa je pokazal, kako težko je doseči kakršnokoli spremembo. Zato se v članku posvetimo konceptoma, ki na drugačen način, v eksistencialni stiski in družbenih pretresih, opišeta mehanizem revitalizacije duha. Obravnavali bomo dva avtorja, Ibn Haldūna in G. W. F. Hegla, ki v udobju, izobilju in varnosti prepoznata erozijo človekovega duha. Pandemija je prelomila z metafiziko prisotnosti, na kateri temelji narativ znanstvene preračunljivosti sveta. Prav ta okoliščina lahko prinese tako globino preloma, ki sproži porajanje alternativnih oblik sobivanja.

Rok Svetlič

\section{Possible perspectives for a positive interpretation of the COVID-19 pandemic}

Keywords: Pandemic, Ibn Haldūn, Hegel, Belicism

The article focuses on a specific aspect of the COVID-19 pandemic, which represents a strong counterpoint to the prevailing response to it. Instead of analysing the problems it has caused, we will ask whether a pandemic can bring an opportunity to revitalise the Western spirit. The search for alternative concepts of coexistence, which will reach beyond the materialistic satisfaction of the individual, profit maximisation and related ecological challenges, is a constant 
striving of post-war Europe. But the stubborn autopoetic mechanism of the dominant narrative has demonstrated how difficult it is to achieve any social change. Therefore, in this article we focus on two concepts that describe the mechanism of revitalisation of the spirit in a different manner, in existential danger and social turmoil. We will consider two authors, Ibn Haldūn and G.W.F. Hegel, who both recognise the erosion of the human spirit in comfort, abundance, and security. The pandemic broke with the metaphysics of presence on which the narrative of the scientific computability of the world is based. It is precisely this circumstance that can represent such a depth of break that can cause the emergence of alternative forms of coexistence.

\section{O avtorju}

Rok Svetlič (znanstveni svetnik) je doktor filozofije in pravnik. Zaposlen je pri Znanstveno-raziskovalnem središču Koper, kjer je predstojnik Pravnega inštituta. Poglavitna področja njegovega raziskovanja so nemška klasična filozofija, filozofija prava in filozofija zgodovine. Med drugim je objavil sedem monografij, od tega dva prevoda. Naslov: Linhartova 68, 1000 Ljubljana. E-naslov: rok.svetlic@guest.arnes.si.

\section{About the author}

Rok Svetlič (scientific counsellor) has a PhD on the field of philosophy, as well as a law degree. He works at the Science and Research Center - Koper, where he is the Head of the Institute of Law. The main areas of his research are German classical philosophy, the philosophy of law and philosophy of history. Among other works he has published seven monographs, two of which are in translation. Address: Linhartova 68, 1000 LJ. Mail: rok.svetlic@ guest.arnes.si. 